\title{
SKELETAL-RELATED EVENTS (SRE) IN PROSTATE CANCER: A REPORT OF TWO CASES
}

\author{
Anak Agung Ngurah Oka Diatmika ${ }^{1}$, Sunaryo Hardjowijoto ${ }^{1}$ \\ ${ }^{1}$ Department of Urology, Faculty of Medicine, Universitas Airlangga, Surabaya, Indonesia/Dr. Soetomo General \\ Academic Hospital, Surabaya, Indonesia
}

\begin{abstract}
A skeletal-related event (SRE) is an event occurring due to bone metastasis in prostate cancer. SREs are usually marked by pain, pathological fractures, spinal cord compression, hypercalcemia, or bone metastasis requiring radiotherapy or operation. Case I: A 64-year-old male was diagnosed with a pathological fracture of the left femur. Thoracal CT scan showed osteoblastic lesions in the thoracal vertebrae, sternum, clavicle, and humeral head. Spinal MRI showed destruction of the cervical to sacral vertebral bodies. The histopathological result with Adenocarcinoma Gleason scores 8 (4+4) and an initial prostate-specific antigen (PSA) level of 689,7 $\mathrm{ng} / \mathrm{dL}$. Afterward, subcapsular orchiectomy was performed. However, his PSA level was still high (>100 $\mathrm{ng} / \mathrm{dL}$ ) even after serum testosterone had reached a castration level. The patient died during the first chemotherapy using docetaxel. Case II: A 61-year-old male was diagnosed with inferior paraplegia and neurogenic bladder, paraparesis, urinary retention, and pain in the flank area. Spinal MRI showed a pathological compression fracture of the 8th thoracic vertebrae. Thoracal CT scan showed costal and 8th thoracal vertebrae destruction as well as multiple nodules in the lungs. Histological results with Adenocarcinoma Gleason score 9 (4+5) and an initial PSA level of 750 ng/dL. Afterward, subcapsular orchiectomy was performed. Serum testosterone reached castration level with the lowest PSA concentration of 21.6 g/dL. The patient declined chemotherapy and agreed to palliative treatment. He died one year after diagnosis. A high PSA level (>500 $n g / d L)$ could potentially be used as a predictor for severe SRE.
\end{abstract}

Keywords: Prostate cancer; skeletal-related event; bone metastasis; bone pain; mcrpc; disease

\section{ABSTRAK}

Skeletal-related event (SRE) adalah kejadian-kejadian yang berhubungan dengan adanya metastase tulang pada kanker prostat. SRE ditandai dengan nyeri tulang, fraktur patologis, kompresi spinal cord, hiperkalemia atau metastase tulang yang memerlukan radiasi/operasi. Kasus I: Laki-laki 64 tahun, dengan fraktur patologis proximal femur kiri, mengeluh nyeri pada tulang belakang, panggul dan paha. CT scan thorax menunjukkan lesi blastik pada corpus vertebra thorakal, sternum, klavikula dan kaput humerus. Pada MRI spine menunjukkan destruksi korpus vertebra cervical hingga sakrum. Hasil histopatologi menunjukkan suatu adenocarcinoma dengan gleason score 8 (4+4), dengan PSA awal 689,7 ng/dL. Setelah dilakukan subcapsular orchidectomy, nilai PSA masih >100ng/dL walaupun testosteron telah mencapai level kastrasi. Pasien ini meninggal saat menjalani kemoterapi pertama dengan regimen docetaxel. Kasus II: Laki-laki 61 tahun, dengan paraplegia inferior dan neurogenic bladder, mengeluh lemah pada kedua kaki, retensi urin dan nyeri pada pinggang. Pada MRI spine tampak fraktur kompresi patologis pada vertebra thorakal 8. Pada CT Scan Thorax, tampak destruksi kosta dan vertebra thorakal serta multipel nodul pada paru. Hasil histopatologi menunjukkan suatu adenocarcinoma dengan gleason score 9 $(4+5)$ dengan nilai PSA awal 750ng/dL. Setelah dilakukan subcapsular orchidectomy, testosteron mencapai level kastrasi dengan nilai PSA terendah 21,6 ng/dL. Pasien ini menolak kemoterapi dan menjalani terapi paliatif kemudian akhirnya meninggal 1 tahun sejak terdiagnosa. Nilai PSA awal yang sangat tinggi (pada kasus kami >500ng/dL) dapat digunakan sebagai prediktor dari kejadian SRE yang berat.

Kata kunci: Kanker prostat; skeletal-related event; metastase tulang; nyeri tulang; mcrpc; disease

Correspondence: Anak Agung Ngurah Oka Diatmika, Department of Urology, Faculty of Medicine, Universitas Airlangga, Surabaya, Indonesia/Dr. Soetomo General Academic Hospital, Surabaya, East Java 60286. Email: di4tmik4@gmail.com.

pISSN:2355-8393 • eISSN: 2599-056x • doi: 10.20473/fmi.v57i3.25250

- Fol Med Indones. 2021;57:250-255 • Submitted 05 Feb $2021 \bullet$ Received 03 May $2021 \bullet$ Accepted 23 Jun 2021

- Open access under CC-BY-NC-SA license • Available at https://e-journal.unair.ac.id/FMI/ 


\section{INTRODUCTION}

Prostate cancer is the second most-common malignancy diagnosed in men after lung cancer. It is estimated at 1.2 million cases all over the world in 2018, comprising $11.6 \%$ of all cancer diagnoses (Bray et al 2018). The prevalence of prostate cancer at the age of less than 30 years old is only $5 \%$, but the risk increases up to $59 \%$ among patients aged 79 years old (Bell et al 2015). The most common sites for prostate cancer metastasis are bones (84\%), lungs (46\%), non-regional lymph nodes (10.6\%), and liver (10.2\%) (Petrakis et al 2015; Hussain et al 2016). Around 90 percent of men who died from prostate cancer have bone metastases. The most common type of bone metastasis is osteoblastic (95\%) found in the axial bones, especially the spine (So et al 2012; Kirakoya et al 2017).

Skeletal-related events (SREs) are events related to bone metastases in prostate cancer. SRE can be characterized by bone pain, pathological fractures, spinal cord compression, hypercalcemia, or bone metastases requiring radiation or bone surgery (So et al 2012; Gartrell et al 2015). The most common symptoms of SRE are bone pain, spinal cord compression and pathological fractures in 11,9\% of patients (Kawai et al 2019, Guzik 2017). SRE commonly occur among patients with metastatic castrate-resistant prostate cancer (mCRPC), majorly affecting the quality of life (QoL) of patients since it causes severe pain and increases the risk of mortality and medical costs. Prostate cancer patients receiving androgen deprivation therapy (ADT) with a Gleason score (GS) of 8 to 10 have a high risk of suffering from SRE (Hussain et al 2016).

\section{PRESENTATION OF CASES}

\section{Case I}

A 64-year-old man with a $40 \%$ Karnofsky score diagnosed with pathological fractures in the left proximal femur, complained of having pain in the spine, pelvis, and thighs regions with a Visual Analogue Scale (VAS) of 8 out of 10. He also had difficulties moving his legs and urinary incontinence. Based on the physical examination, lower extremity edema, paraplegia, sensory hypoesthesia up to thoracal (Th) 11 level, nodules in both prostate lobes, and decreased anal sphincter tone were found. The histopathological results from the biopsy were adenocarcinoma with GS $8(4+$ 4), with a baseline PSA of $689.7 \mathrm{ng} / \mathrm{dL}$.

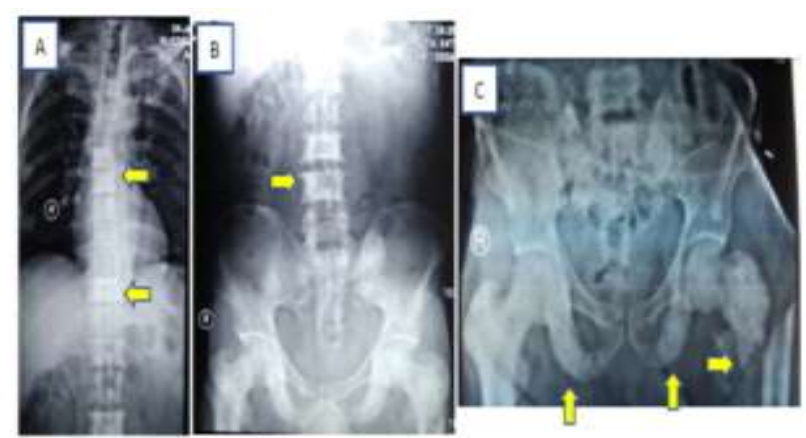

Figure 1. Bone Survey Examination (A, B) showed blastic lesions of the thoracal-lumbar vertebrae, (C) blastic lesions of the right-left femoral heads, left sacrum, left inferior pubis ramus, and pathologic fractures on the left proximal femur

Ultrasound examination (USG) of the abdomen revealed prostate volume $\pm 29.9 \mathrm{~cm} 3$ in size. Bilateral moderate hydronephrosis was suspected due to prostate infiltration at the ureteric orifice. Bone survey examination showed blastic lesions in the body of the 6th Th vertebra to the 2 nd lumbar vertebral body, right and left femoral heads, right-left inferior pubic ramus, and pathological fractures in the left proximal femur shown in Figure 1.

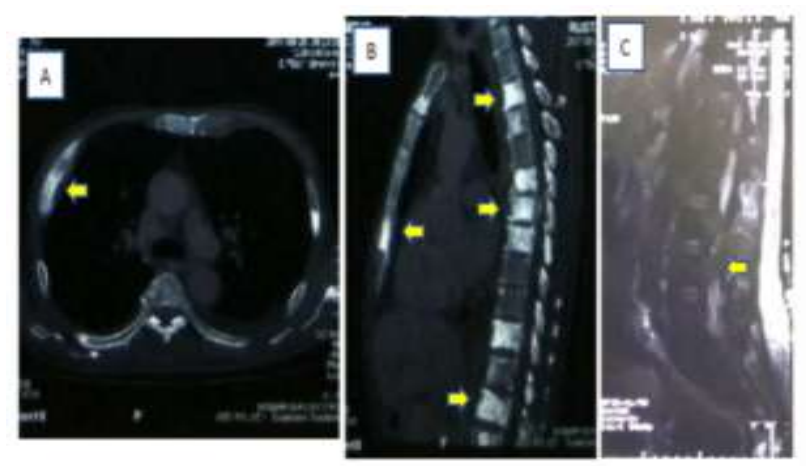

Figure 2. (A, B) Thorax CT scan showed blastic lesions in the vertebral bodies, sternal bodies of manubrium, and clavicle; (C) MRI showed bone destruction in the cervical vertebral bodies to the sacrum 
Table 1. Evaluation results of PSA and testosterone examination

\begin{tabular}{|c|c|c|c|c|c|c|c|c|}
\hline & \multicolumn{2}{|c|}{$\begin{array}{c}\text { TURP } \\
(07 / 11 / 16)\end{array}$} & \multicolumn{2}{|c|}{$\begin{array}{c}\text { LHRH Aganis t + A.DT } \\
(17 / 03 / 17)\end{array}$} & \multicolumn{2}{|c|}{$\begin{array}{c}\text { LHRH Aganis t + A.DT } \\
(05 / 07 / 17)\end{array}$} & \multicolumn{2}{|c|}{$\begin{array}{c}\text { Subcapsular } \\
\text { OrchidectamyD/S } \\
(08 / 09 / 17)\end{array}$} \\
\hline & $31 / 10 / 16$ & 07/03/17 & $14 / 03 / 17$ & $18 / 0417$ & $04 / 07 / 17$ & $11 / 07 / 17$ & $25 / 07 / 17$ & $16 / 10 / 17$ \\
\hline PSA (ng/ml) & 689,7 & 561 & $>100$ & 93,74 & $>100$ & 258 & $>100$ & $>100$ \\
\hline Testosterone (ng/dL) & & & 39,4 & 0,21 & 39,82 & & & 11,8 \\
\hline
\end{tabular}

Thoracal Computed Tomography (CT) scan showed no lung metastatic process, however multiple blastic lesions were seen in the Th vertebral bodies, sternum, clavicle, and humeral head as shown in Figure 2. Moreover, Magnetic Resonance Imaging (MRI) of the spine showed destruction of the cervical spine bodies to the sacrum in Figure 3. The patient received ADT therapy and luteinizing hormone-releasing hormone (LHRH) agonist injection for 9 months and underwent a sub-capsular orchidectomy as shown in Table 1. However, the PSA level was still more than $100 \mathrm{ng} / \mathrm{dL}$, even though the testosterone had reached castration level, so that the patient was diagnosed with mCRPC.

From the results, it was decided to give chemotherapy with Docetaxel $75 \mathrm{mg} / \mathrm{m} 2$ every 3 weeks for 10 cycles and $2 \times 5 \mathrm{mg}$ prednisone and $1 \times 50 \mathrm{mg}$ Bicalutamide. Radiotherapy was planned and cervical thoracic lumbosacral orthosis (CTLSO) was prescribed for fracture management. A combination of morphine and non-steroid anti-inflammatory drug (NSAID) was prescribed for pain management. Unfortunately, this patient died during the first cycle of chemotherapy treatment due to septic shock.

\section{Case II}

A 61-year-old man with a $60 \%$ Karnofsky score with inferior paraplegia and neurogenic bladder, complained of weakness in both legs, urinary retention, and pain in the back region. Based on the physical examination, there was paraplegia, hypoesthesia up to the Th 11 level, nodules in both prostate lobes, and decreased anal sphincter tone. The histopathological results from prostate biopsy were adenocarcinoma GS $9(4+5)$, with PSA level of $750 \mathrm{ng} / \mathrm{dL}$.

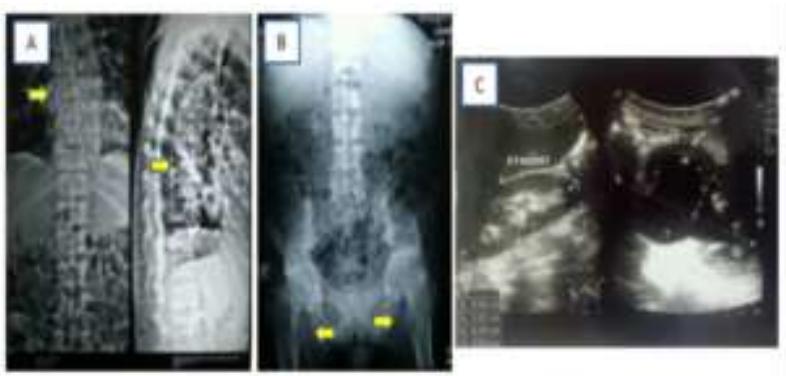

Figure 3. (A, B) Bone survey examination showed compression fracture and blastic and lytic lesions in the thoracic vertebrae, (B) multiple lytic lesions in the femur region and pubic rami, (C) abdominal ultrasound examination showed severe hydronephrosis of the left kidney.

Abdominal ultrasound showed severe hydronephrosis of the left kidney due to infiltration of the left ureteric orifice discovered during cystoscopy. Bone survey examination showed a metastatic process in the vertebrae, pelvis, and femur regions. Thoraco-lumbosacral plain radiograph showed compression fractures of the Th 8 vertebrae and blastic as well as lytic lesions in the Th 8, 9, and 10 vertebrae. Pelvic radiograph showed that there were multiple lytic lesions in the major trochanter and bones of the right-left femur, 1/3 proximal right femur, and bilateral inferior pubic rami. 


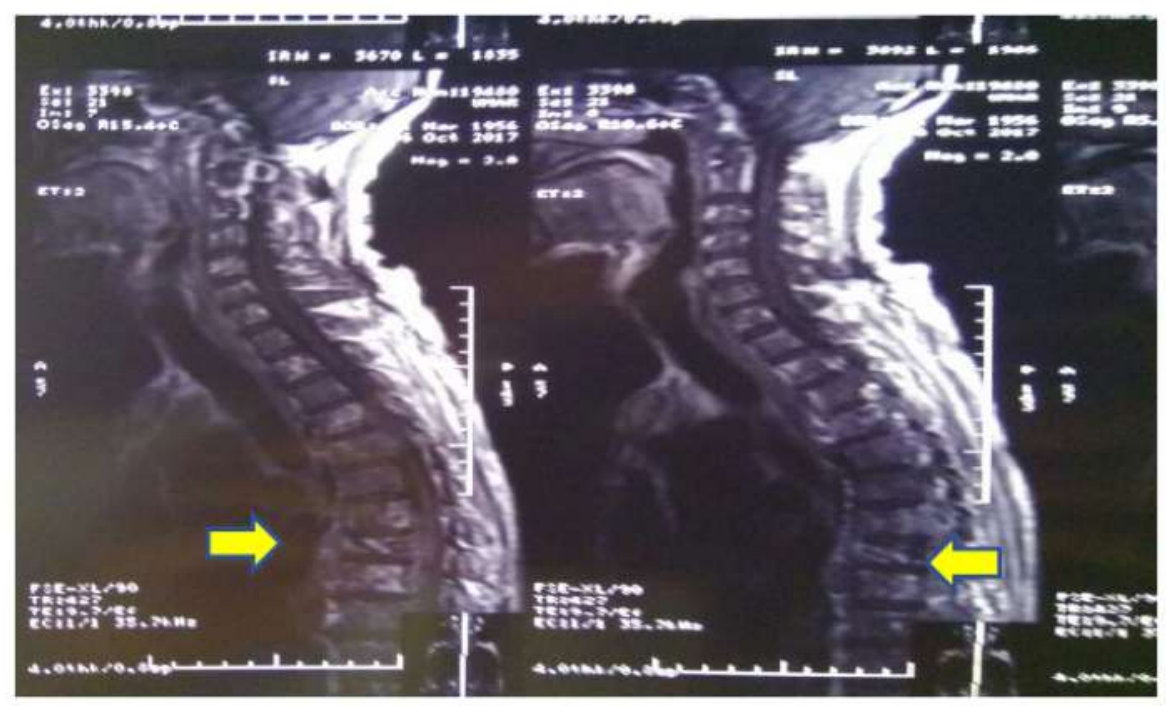

Figure 4. Lumbosacral MRI showed pathological compression fractures of the Th vertebrae and increased paravertebral soft tissue mass
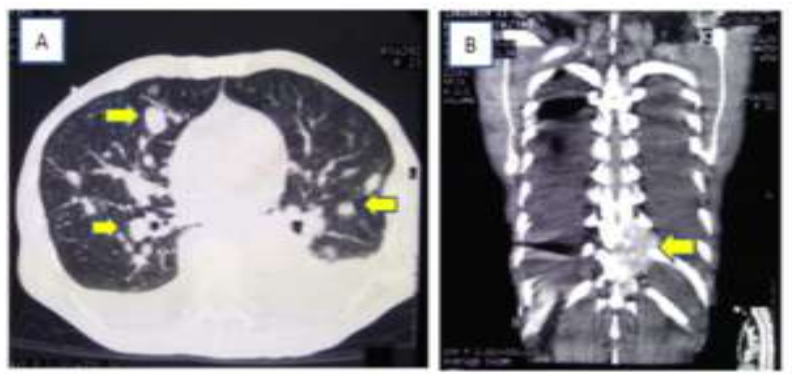

Figure 5. Thorax CT scan; (A) multiple nodules on the right and left lungs; (B) showed destruction of the transverse processes of the Th 10-12 vertebrae

Spine MRI examination showed pathological compression fractures of Th 8 vertebra, an increase in thoracic paravertebral soft tissue mass from Th 4 to 11 vertebrae, infiltrating the spinous processes and bilateral pedicles causing severe central canal stenosis shown in Figure 4. A thorax CT scan was performed due to pulmonary metastasis suspicion. There were multiple nodules of the superior lobe on the right and left lungs. Moreover, it showed destruction of the left 2nd, 3rd, and 6th left costae and the right 1st, 2nd, 3rd, and 4th costae, as well as the transverse processes of the left Th 10 to 12 vertebrae shown in Figure 5.

After subscapular orchiectomy, testosterone achieved the castration level with the lowest PSA level of 21.6 ng/dL. The patient refused chemotherapy and only received palliative therapy as well as conservative therapy using Thoraco-Lumbo-Sacral Orthosis (TLSO). He died one year after diagnosed.

\section{DISCUSSION}

SREs are commonly found in some complications due to prostate cancer, especially in castrate-resistant prostate cancer (CRPC). Bone metastases could disrupt bone homeostasis by disrupting the balance between osteoblastic bone formation and osteoblastic bone destruction. Bone metastases could cause a number of complications including hypercalcemia, bone marrow failure, and SRE. Half of the patients with prostate cancer and bone metastases will experience SREs within 2 years if left untreated (So et al 2012).

Tumour cells migrate towards the bone depend on a gradient of chemokines and ligands released by the bone marrow. Then, tumour cells parasitize the bone microenvironment for haematopoietic stem cells (HSC) and become dormant in the bone marrow. Receptor Activator of Nuclear Factor $k \beta$ ligand (RANKL) is a major mediator of normal bone remodelling and binds to its receptor RANK on the surface of osteoclast progenitors, resulting in osteoclast differentiation and bone resorption. Disseminated prostate cancer cells enhance RANKL expression on osteoblasts by secreting parathyroid hormone-related protein leading to osteoclast genesis and increased bone resorption, which in turn creates space for tumour cells to grow within the bone marrow (El-Badri et al 2019).

The two patients were diagnosed with mCRPC based on the PSA levels, which were high $(>2 \mathrm{ng} / \mathrm{ml})$, even though the testosterone had reached the castration level of $(<50 \mathrm{ng} / \mathrm{dL})$. The type of lesion of bone metastases in both patients was consistent with the bone metastases characteristics of prostate cancer which was 
usually osteoblastic. Although in the second patient, there was also lytic lesion of the femur and ramus pubis. Bone metastases cases in prostate cancer with diffuse osteolytic lesions were also reported by Idowu (2018). The signs of spinal cord compression were the main complaints of patients with SRE shown by spinal pain. The symptoms of impending SRE might include local or radiating pain in the back region, weakness in the lower extremities, or sensory dysfunctions in the form of urinary retention or incontinence (Partin et al 2020).

Due to the high morbidity and mortality rates among patients with SRE, therapy to prevent the occurrence of SRE is highly important. One of which is vitamin D and calcium supplementation to prevent osteoporosis. The administration of estrogen can also increase bone density and reduce the risk of fracture. Estradiol patch was said to increase bone density by $3.6 \%$ in vertebrae and $2.1 \%$ in the femoral neck (Safriadi 2013; Partin et al 2020). Selective estrogen receptor modulators (SERMs), such as raloxifene and toremifene could also protect bone resorption and increase $1 \%$ bone mineral density (BMD) in the lumbar vertebrae. In addition, the administration of bicalutamide monotherapy with 150 mg nonsteroidal antiandrogen per day could also increase $2.5 \%$ of BMD and prevent fractures (Partin et al 2020). Serum calcium should be measured in patient starting therapy with ADT and monitored during treatment. Daily calcium $(>500 \mathrm{mg})$ and vitamin D $(\geq 400$ IU) were recommended in all patients, except in case of hypercalcemia (Mottet et al 2020).

Bisphosphonate and denosumab are also therapies to slow and prevent SREs by inhibiting bone resorption by osteoclasts. From several bisphosphonates available, only zoledronic acid can reduce SREs. The administration of zoledronic acid $4 \mathrm{mg}$ every 3 weeks can reduce $33 \%$ of SREs compared to placebo, as well as reducing pain. Zoledronic acid is not recommended to patients with impaired kidney function. Denosumab also plays a role in reducing bone resorption and increasing bone mass (Zustovich \& Fabiani 2014). In a study comparing the administration of $60 \mathrm{mg}$ denosumab every 6 months in prostate cancer patients with androgen deprivation therapy (ADT), reduction of bone tissue erosion and vertebral bone fractures incidence were apparent compared to those given placebo. The administration of denosumab did not depend on kidney function due to its elimination through the reticuloendothelial system (RES). Thus, there was no contra-indication to give denosumab in patients with impaired kidney function or with hemodialysis. In a study comparing zoledronic acid and denosumab, the two therapies were similar in extending the overall survival and reducing disease progression as well as adverse occurrences, such as hypocalcemia and osteonecrosis (Zustovich \& Fabiani 2014; Gartrell et al 2015).

\section{CONCLUSION}

Skeletal-related event (SRE) was serious complications of bone metastases in patients with metastatic castration-resistant prostate cancer (mCRPC). Spinal cord compression was the most common complaint in SRE patients. The incidence of SREs could increase morbidity in patients, because it caused severe pain, reduced the quality of life (QoL), increased medical costs and increased the risk of mortality. Even though there were many therapeutic options to increase bone density, the incidence of SREs remained high in mCRPC cases, so that the prevention of bone metastases and SREs in prostate cancer should be conducted earlier.

\section{REFERENCES}

Bell KJL, Mar CD, Wright G, et al (2015). Prevalence of incidental prostate cancer: A systematic review of autopsy studies. International Journal of Cancer 137, 1749-1757.

Bray F, Ferlay J, Soerjomataram I, et al (2018). Global cancer statistics 2018: GLOBOCAN estimates of incidence and mortality worldwide for 36 cancers in 185 countries. CA: A Cancer Journal for Clinicians 68, 394-424.

El Badri SAM, Salawu A, Brown JE (2019). Bone health in men with prostate cancer: Review article. Current Osteoporosis Reports 17, 527-537.

Gartrell BA, Coleman R, Efstathiou E, et al (2015). Metastatic prostate cancer and the bone: Significance and therapeutic options. European Urology 68, 850-858.

Guzik G (2017). Oncological and functional results of the surgical treatment of vertebral metastases in patients with multiple myeloma. BMC Surgery 17, $1-8$.

Hussain A, Aly A, Mullins CD, et al (2016). Risk of skeletal related events among elderly prostate cancer patients by site of metastasis at diagnosis. Cancer Medicine 5, 3300-3309.

Idowu BM (2018). Prostate carcinoma presenting with diffuse osteolytic metastases and supraclavicular lymphadenopathy mimicking multiple myeloma. Clinical Case Reports 6, 253-257.

Kawai AT, Martinez D, Saltus CW, et al (2019). Incidence of second primary malignancies in patients with castration-resistant prostate cancer: An observational retrospective cohort study in the United States. Prostate Cancer 2019, 1-7. 
Kirakoya B, Pare AK, Abubakar BM, et al (2017). Prostate cancer presenting with parietal bone metastasis. Case Reports in Urology 2017, 1-3.

Mottet N, Cornford P, Bergh RCN, et al (2020). EAU EANM - ESTRO - ESUR - SIOG guideline on prostate cancer. European Association of Urology 79, 243-262.

Partin AW, Dmochowski R, Kavousii L, et al (2020). Campbell Walsh Wein Urology: 11th edition. Amsterdam, Elsevier Health Sciences.

Petrakis D, Pentheroudakis G, Kamina S, et al (2015). An unusual presentation of a patient with advanced prostate cancer, massive ascites and peritoneal metastasis: Case report and literature review. Journal of Advanced Research 6, 517-521.

Safriadi F (2013). Bone metastases and bone loss medical treatment in prostate cancer patients. Acta medica Indonesiana 45, 76-80.

So A, Chin J, Fleshner N, et al (2012). Management of skeletal-related events in patients with advanced prostate cancer and bone metastases: Incorporating new agents into clinical practice. Journal of the Canadian Urological Association 6, 465-470.

Zustovich F, Fabiani F (2014). Therapeutic opportunities for castration-resistant prostate cancer patients with bone metastases. Critical Reviews in Oncology/Hematology 91, 197-209. 